\title{
Ureteric Hemorrhage
}

National Cancer Institute

\section{Source}

National Cancer Institute. Ureteric Hemorrhage. NCI Thesaurus. Code C78664.

Bleeding originating from the ureter. 